\title{
Gynecology and Gynecological Nursing Theories and Practices in Traditional Chinese Medicine: Review on the Ancient Literatures
}

\author{
Xiangeng Zhang ${ }^{1 \#}$, Hui Zhang ${ }^{2 \#}$, Xiaoli Liang ${ }^{1}$, Qin Liu ${ }^{1}$, Miqu Wang ${ }^{2 *}$ \\ ${ }^{1}$ Nursing School, Chengdu University of Traditional Chinese Medicine, Chengdu, China \\ ${ }^{2}$ Genetics Laboratory, Chengdu University of Traditional Chinese Medicine, Chengdu, China

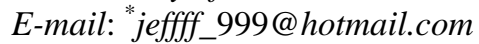 \\ Received April 26, 2011; revised May 8, 2011; accepted May 13, 2011
}

\begin{abstract}
Objective: the study is aimed to introduce the developing history of gynecology and gynecological nursing in traditional Chinese medicine (TCM). Study Design: the development of gynecology and gynecological nursing consists of six periods in Chinese history. They are: 1) budding stage represented by the inscriptions of Nü (female) on oracle bones; 2) physiological development stages of women; 3) specialized chapters of gynecology in TCM; 4) features of gynecological nursing; 5) monograph of gynecology and gynecological nursing; 6) integration of ancient gynecological nursing perceptions. Results: TCM has a profound understanding of gynecology and gynecological nursing. For period one, the inscriptions of Nü (female) on oracle bones is the symbol of the budding stage. For period two, physiogenesis stages of women are recorded in The Yellow Emperor of Classics of Inner Medicine. For period three, the specialized chapters of gynecology appeared, represented by Golden Chamber, Woman. For period four, the features of gynecological nursing were elaborated in Essential Prescriptions Worth A Thousand Gold including menstruation, depression, yin-dampness, and menopause. For period five, monographs of gynecology and gynecological nursing represented by Good Comprehensive Woman Formulae appeared. For period six, Integrative studies of gynecological nursing perceptions were carried out with the representation by Integrated Ancient and Modern Books. Conclusion: TCM gynecology and gynecological nursing harbors a long history of treating and nursing gynecological disorders. With therapeutic and nursing modalities, they are effective systems of understanding and managing woman health as proven by medical literatures, clinical benefits and basic research studies.
\end{abstract}

Keywords: TCM Gynecology, TCM Gynecological Nursing, Traditional Chinese Medicine (TCM)

\section{Introduction}

TCM, a medical system of diagnosis and health-care approaches, has a long history of over 2000 years. It has evolved into a well-developed, coherent system of medicine that uses several modalities to treat and prevent illness. The most commonly applied therapeutic methods include acupuncture, moxibustion, herbal remedies, diet, meditation, and both static and moving exercise [1,2]. In TCM, gynecology is one of the main branches with unique features [3]. The developing history of TCM gynecology, abundant gynecological nursing theories, approaches, and concepts are involved. Extensive litera-

"These two authors contribute equally to this work. tures are recorded on disorders of menstruation, leucorrhea, pregnancy, delivery, lactation, and etc. [4]. There are specialized chapters, monographs available on nursing which is not inferior to gynecological, obstetric, and reproduction nursing cognitions in ancient Greece [5], Rome [6], Egypt [7], and India [8]. TCM has increasing popularity worldwide especially for acupunctural and herbal therapy for pain, diabetes, menopause syndrome (MPS) and other chronic diseases. It's very important to fully understand the developing course of a specific field. Only in this way, can the practitioner have an all-round perception of a subject. Zhang et al. [9] reviewed the developing history of diabetes in TCM. To our knowledge there is yet no review on the developing history of TCM gynecology and TCM gynecological nursing in 
published literatures. However nowadays, the understanding of gynecological nursing of TCM is merely limited and awaits popularization. We extensively and intensively mined the literates on TCM gynecological nursing to draw rational attention to this unique nursing system. TCM gynecology and nursing have a comprehensive coverage of woman's disorders including menstruation, coitus, fertilization, antenatal training, pregnancy, dystocia, children rearing, and women's hygiene, daily care, activities, emotion, diet, psychology, remedy, massage, and gereology [10]. This study might broaden the knowledge of gynecology and gynecological nursing.

\section{Methods}

The development of gynecology and gynecological nursing in TCM consists of six periods in the recorded Chinese history based on Zhang's classification of Chinese medical history and the periodization of China's history [9]. The developing history includes as follows: 1) budding stage represented by the inscriptions for Nü (female ) on oracle bones, 1700 B.C.-256 B.C., (Sang dynastyZhou dynasty); 2) physiogenesis stages of woman recorded in The Yellow Emperor of Classics of Inner Medicine (Huang Di Nei Jing), 256 B.C.-8 A.D. (Zhou dynasty-Western Han dynasty); 3) the specialized chapters of gynecology in TCM represented by Golden Chamber, Woman (Jin Kui Yao Lüe·Fu Ren Pian), 8 A.D.-589 A.D. (Xin Dynast- Northern and Southern dynasties); 4) features of gynecological nursing in TCM represented by the content in Essential Prescriptions Worth A Thousand Gold (Qian Jin Yao Fang), 589-960 (Sui dynasty-Five Dynasty); 5) monograph of gynecology and gynecological nursing in TCM represented by Good Comprehensive Woman Formulae (Fu Ren Da Quan Liang Fang), 960 A.D.-1368 A.D. (Song dynastyJin and Yuan dynasty); 6) integration of ancient gynecological nursing perceptions represented by Integrated Ancient and Modern Books (Gu Jin Tu Shu Ji Cheng), 1368 A.D.-1912 A.D. (Ming dynasty-Qing dynasty). All the representative literatures have a high reputation in the field of Chinese medical literatures with their irreplaceable status and role in the development of gynecology and gynecological nursing in TCM.

\section{Results}

\subsection{Budding Stage Represented by the Inscriptions for Nü (Female) on Oracle Bones (1700 B.C.-256 B.C.)}

Oracle and bones inscription was the first mature script of China over 3000 years ago, which was used to divine and record in royal. The character of Nü (Figure 1, I) in this script system means a woman sitting straight with hands crossing and legs bending. In the same system, plenty of characters related to Nü were discovered such as $M u$ (mother), Mei (each), Yun (pregnancy), Yu (delivery), Fu (woman), Ren (gestation), Hao (good), Ru (breast), and so on (Figure 1).

There are various characters in Chinese language based on $N \ddot{u}$ and $M u$ represented by $Y u n, Y u$, and $R u$. Yun (Figure 1, IV) consists of Nü on the top of Zi (infant), which means a potbellied woman with a big head fetus inside the abdomen. $\mathrm{Yu}$ (Figure 1, V) consists of $N \ddot{u}$ on the upper-left side of bleeding $Z i$, which means a woman is delivering and bleeding. $R u$ (Figure 1, IX) consists of woman surrounding a neonate, which means a mother is holding and breeding a baby with exposed breasts. It can be seen that in oracle and bones inscription, life and generation are reflected by the status of a mother holding a baby. Her gesture, having knees bent, breasts exposed and baby held, is the most graceful script. Yun, $Y u$, and $R u$ are amazing annotations of the three courses of woman: pregnancy, delivery, and fostering. Meanwhile Hao (Figure 1, VIII) consists of a male on the left side of a female, which means good and beautiful and is employed to praise above courses. Oracle and bones inscriptions also have lively records on the courses of pregnancy and fostering. For instance, divinatory symbols indicating the good and ill luck of pregnant woman and fetus, dystocia and parturient disease. Meanwhile there is a certain name of all the gynecological disorders, Ji Yu or illness of gestation [11].

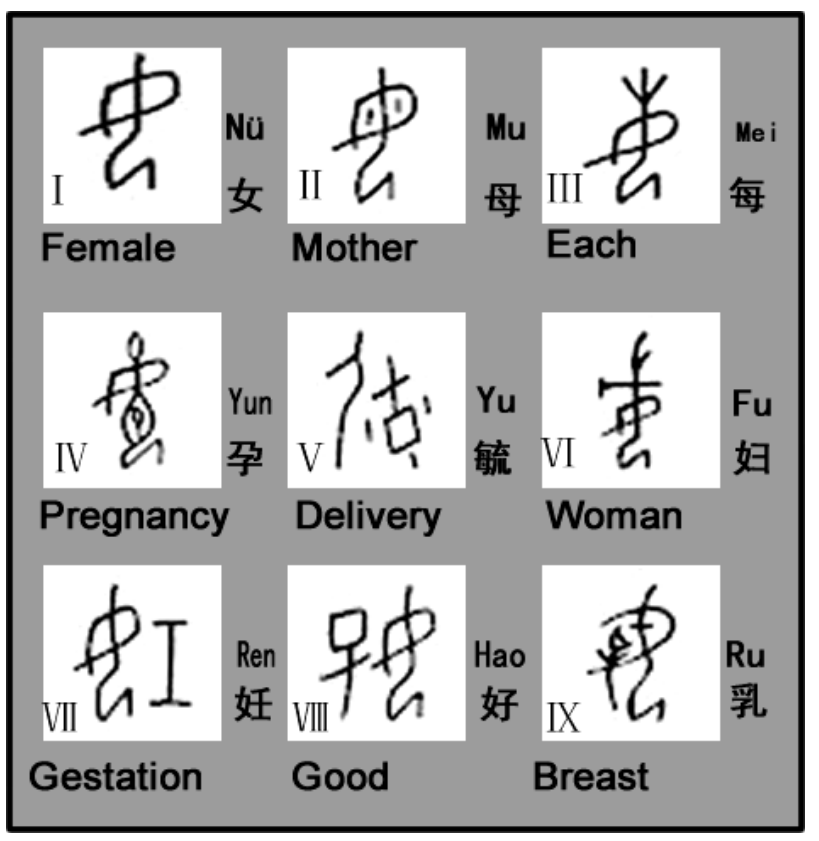

Figure 1. Oracle and bones inscriptions correlated to Nü. 


\subsection{Physiological Growth and Development Stages of Woman Recorded in The Yellow Emperor of Classics of Inner Medicine (Huang Di Nei Jing), 256 B.C.-8 A.D.}

The Yellow Emperor of Classics of Inner Medicine (Huang Di Nei Jing) is the an agglomeration of Chinese life science before 8 A.D., which is the foundation of TCM including physiology, pathology, anatomy, psychology, health prevention, yin yang, five elements, meridian, organs, etiology, pathogenesis, diagnosis, and therapy [12]. It also documents the physiological development of woman and gynecological disorders. It is in the first chapter that the whole growing course are discussed (Table 1).

In this book, various gynecological disorders and their pathogen, diagnosis and principle of therapy are involved, such as infertility, amenorrhea, aphonia during prenatal period, leukorrhagia, Zheng Jia (concretions and conglomerations), large intestine cancer, and uterine cancer. Meanwhile, the first gynecology formula is recorded in the book, Si Wu Zei Gu Yi Lu Ru Wan (four of cuttlefish to one of madder pill) which is used to treat threaten abortion, uterine bleeding, and leukorrhagia. It can be seen that TCM already had deep understanding of gynecological disorders, which also gave birth to gynecological nursing in TCM.

During the period 256 B.C.-8 A.D, genealogical literatures were found in non-medical books. The First Year of Zuo Zhao (Zuo Zhao Yuan Nian) discusses the pathogen of genealogical disorders. Zuo Zhuan records the close relationship between physiology and psychology which can interact. It also records that woman is susceptible to psychology illness because of over-thinking, over-working, and irritability. All the documentations imply the sprout of nursing of psychology, diet and daily life.

\subsection{Special Chapters on Gynecology in TCM Represented by Golden Chamber, Woman (Jin Kui Yao Lüe, Fu Ren Pian), 8 A.D.-589 A.D.}

Zhongjing Zhang wrote the first specialized chapters on gynecological disorders, Golden Chamber, Woman (Jin Kui Yao Lüe, Fu Ren Pian) which discussed gestational disorders, postpartum disorders, and gynecological miscellaneous diseases separately in three chapters. They are Chapter 20, Disease, Pulse, Syndrome and Treatment of Pregnant Woman (Fu Ren Ren Shen Bing Mai Zheng), Chapter 21, Disease, Pulse, Syndrome and Treatment of Postpartum Woman (Fu Ren Chan Hou Bing Mai Zheng Zhi), and Chapter 22, Miscellaneous Diseases, Pulse, Syndrome and Treatment of Woman (Fu Ren Za Bing Bing Mai Zheng Bing Zhi). His understanding on gynecology has been playing directive role for later researches. The book involves the physiological features and all-round disorders of women. For instance, it is recorded in Chapter 21 that, there are three possible diseases for women who have just given birth, convulsion, Yu Mao (dizziness, vertigo and depression) and dyschezia. The pathogenesis of convulsion is that a newly delivered woman has blood deficiency and hidrosis, and is susceptible to have wind invaded. The pathogenesis of Yu Mao is that blood collapse and hidrosis lead to cold. The reason of dyschezia is exhausted fluids and stomach dryness. Therefore, he has been honored as the initiator who was specialized in treating gynecological disorders as an interdependent disease.

Zhang's gynecological nursing theory adheres to herbal treatment based on the perception of gynecological features, nursing during the entire process, combinational use of herb and diet, and concern of personal hygiene. In Golden Chanmbe, Disease, Pulse, Syndrome and Treat-

Table 1. Physiogenesis stages of woman recorded in The Yellow Emperor of Classics of Inner Medicine (Huang Di Nei Jing).

\begin{tabular}{ccc}
\hline Age Bracket (years) & Wane and Wax of Qi & Physiological Sings \\
\hline 0 - 7 /first Seven & Ascending kidney Qi & Dental transition, growing hair \\
8 - 14 /second Severn & Smooth of Ren meridian and excess of Taichong meridian & Arrival of Tian Gui (menstuation), pregnancy \\
$15-21 /$ third Seven & Hardened bone and sinews & Extremely lengthened hair, strong constitution \\
$22-28 /$ fourth Seven & Descending Qi of Yangming meridian & Beginning of gaunt face and hair loss \\
$36-42 /$ sixth Seven & Deficiency of upper triple-yang (Taiyang, Yangming, Shaoyang) & General gaunt face, beginning of whitening hair \\
$43-49 /$ seventh Seven & Deficient Ren meridian, reduced Taichong meridian, & Menopause, and inability of fertility
\end{tabular}


ment of Postpartum Woman, Dang Gui Sheng Jiang Yang Rou Tang (tangkuei, fresh ginger, and goat meat decoction) is used to treat mild and persistent abdominal pain. The formula consists of Dang Gui (Angelicate Sinensis Radix) a blood supplementing herb, ginger, and goat meat, which indicate his assertion of diet-herb therapy and the feature of herbal care in TCM. He also pointed out each disease requires different daily life considerations. If the considerations are favorable, the disease is readilier to be cured. Otherwise, the disease is harder to be cured. In summary, individual and locality oriented analysis is necessary to carry out a on-demand nursing based on pattern differentiation [13].

\subsection{Features of TCM Gynecological Nursing Represented by the Record in Essential Prescriptions Worth a Thousand Gold (Qian Jin Yao Fang), 589 A.D.-960 A.D.}

Simiao Sun (581-682) wrote an outstanding medical book named Essential Prescriptions Worth A Thousand Gold (Qian Jin Yao Fang). In his book three gynecology chapters were for the first time placed prior to internal medicine, which indicates the presence as an independent field. In Chapter 1, Generation Demands (Qiu Zi Di $Y i)$, mind-body features of woman is discussed. The treatment of gynecological disorders is complicated because of the physiological features of menstruation, leucorrhea, pregnancy and delivery essential to the first perception which both medical and nursing practitioners must understand.

He has deep perception on menstruation (physiology), depression (psychology), yin-dampness (pathogenesis), and menopause (pathology). He advocates that not only doctor and nurses are responsible for the four issues, but also the parents, husbands and offsprings should be concerned. Thus, a special medical care mode with self-care and family care was formed. In this book abundant details on gynecological nursing were recorded. For instance, when giving birth, the room must be quiet, and the parturient must keep a quiet mood to bear pain and be patient with slow parturition.

\subsection{Monographs of TCM Gynecology and Gynecologic Nursing Represented by Good Comprehensive Woman Formulae (Fu Ren Da Quan Liang Fang), 960 A.D.-1368 A.D.}

When the history of TCM came to the period from Song dynasty (960-1279) to Yuan dynasty (1271-1368) a development summit appeared during which the famous "four schools of Jin and Yuan" formed and TCM nursing achieved an in-depth growth. In that period, monographs of separated clinical departments appeared, such as Good
Comprehensive Woman Formulae (Fu Ren Da Quan Liang Fang) written by Ziming Chen, published in 1237, and Secretes of Pediatric Herbs and Syndrome (Xiao Er Yao Zheng Zhi Jüe) written by Yi Qian, published in 1114. Dongyuan Li (1180-1251) wrote Treatise on the Spleen and Stomach, Nursing Methods of Spleen and Stomach (Pi Wei Lun, Pi Wei Jiang Li Fa). With the appearance of specialized clinical monographs, departmental nursing took shape. Altogether there are more than ten monographs on gynecology and obstetrics.

For instance, Treaties on Ten Dystocias (Shi Chan Lun) written by Zijian Yang in 1098, discussed the pathogen, symptom and aids of ten abnormal deliveries, crossbirth, footling presentation, oblique presentation, injured labor, induced spawning, frozen delivery, heat delivery, umbilical dystocia, sitting position labor, and rolled intestine delivery. The correcting technique of crossbirth or acromio-iliac presentation, a representative technique in dystocia nursing, was 500 years earlier than the record in Europe.

Good Comprehensive Woman Formulae (Fu Ren Da Quan Liang Fang) has been regarded as the agglomeration of gynecology in TCM. It also presents plenty of gynecology nursing issues. There are various chapters named after nursing such as Antenatal Education, Avoidance and Nursing of Child Destruction before Delivery (Tai Jiao Meng, Tai Sha Bi Ji Chan Qian Jiang Hu Fa), Gestation, Gestational Remedy and Nursing Along with the Age of Fetus (Ren Shen Sui Yue Shu Fu Yao Ji Jiang Xi Fa), Puerperium Care, Nursing of Puerpera (Zuo Yue Men, Jiang Fu Yun Fu Lun), Postpartum, Regulation of Postpartum (Chan Hou Men, Chan Hou Tiao Li Fa), and Postpartum, Nursing of Postpartum (Chan Hou Men, Chan Hou Jiang $\mathrm{Hu} \mathrm{Fa}$ ). Meanwhile there are abundant documents on the principles, methods, and details of gynecological nursing. For example, the nursing of menstruation and virginal bleeding must focus on Xue or blood, because only when blood is harmonized, can $Q i$ (the circulating life energy) be harmonized and fetus be safe and delivery be successfully. Another example is that the nursing modalities of rich woman differ from poor woman. Rich woman should not relax in comfort or pleasure, because the lack of exercise gives rise to $Q i$ stagnation and immobility of fetus, which eventually leads to dystocia.

\subsection{The Integration of Ancient Gynecological Nursing Perceptions Represented by Integrated Ancient and Modern Books (Gu Jin Tu Shu Ji Cheng), 1368 A.D.-1912 A.D.}

Ming Dynasty and Qing dynasty are the late stage of ancient China. The integrated study on medical books 
has achieved obvious development in those periods; particularly over one hundred comprehensive medical monographs are cultivated during that time. Most of the comprehensive monographs contain extensive gynecological and gynecological nursing contents. For instance, Zhang's Medical Book (Zhang Shi Yi Tong) written by Shiwan Zhang (1617-1700) includes one chapter named Facing Perinatal Disorders ( $L i n R u$ ) in which 13 issues are discussed, such as Fu Chi or nursing aid, Shang Tai or bleeding, Gan Tai or premature rupture of membrane (PROM), Nan Chan or dystocia, Chan Bian or abnormal phenomenon of labor, Mo Chuai or relieving labor pain, Wo Fa or labor gesture guide, Cui Sheng or expediting child delivery, and Yin Shi Yi Ji or proper and improper life styles. In another book, Ancient and Modern Books,
Comprehensive Medical Books (Gu Jin Tu Shu Ji Cheng Yi Bu Quan Lu), Gynecology (volume 381 - 400) embodies over 100 ancient gynecological books in which 21 books about perinatal care and 187 formulae are involved.

In the developing history of gynecological nursing in TCM, fetus fostering and fetus education are two unique issues. They initiated in Jin dynasty (266-420) and raped in Ming dynasty (1368-1644). Fetus fostering and education have varied and extensive contents including fetus fostering according to different months, formula, surrounding, emotional condition, diet and nutrition, and contraindication (Table 2). Moreover, it involves mate selection, preparation for fertilization, sperm cultivation for man, and blood cultivation for woman. The narrow

Table 2. Summary of the understandings of fetus fostering and education.

\begin{tabular}{|c|c|c|c|c|c|c|c|c|c|}
\hline \multirow[b]{2}{*}{ Months } & \multicolumn{3}{|c|}{ Understanding on Fetus } & \multicolumn{5}{|c|}{ Fetus Fostering and Education } & \multirow[t]{2}{*}{ Disease } \\
\hline & Meridian & $\begin{array}{l}\text { Form of } \\
\text { embryo }\end{array}$ & Physiology & $\begin{array}{c}\text { Daily life } \\
\text { considerations }\end{array}$ & Psychology & Diet & Formula & $\begin{array}{l}\text { Forbidden } \\
\text { meridian for } \\
\text { acupuncture }\end{array}$ & \\
\hline First & $\begin{array}{l}\text { Foot Jueyin } \\
\text { liver (L) }\end{array}$ & $\begin{array}{c}\text { The beginning } \\
\text { of embryo, } \\
\text { dewdrop-like }\end{array}$ & $\begin{array}{l}\text { Accumulation } \\
\text { of Jing } \\
\text { (essence) Qi }\end{array}$ & $\begin{array}{l}\text { Sleep with quiet } \\
\text { surrounding }\end{array}$ & $\begin{array}{l}\text { Avoidance } \\
\text { of fear }\end{array}$ & $\begin{array}{l}\text { Flour and } \\
\text { rice }\end{array}$ & $\begin{array}{c}\text { Wu Ci Ji Tang } \\
\text { (black-bone } \\
\text { chicken decoction) }\end{array}$ & $\begin{array}{l}\text { Foot } \\
\text { Jueyin } \\
\text { liver }\end{array}$ & $\begin{array}{c}\text { Coldness } \\
\text { and less } \\
\text { pain }\end{array}$ \\
\hline Second & $\begin{array}{c}\text { Foot } \\
\text { Shaoyang } \\
\text { gallbladder }(\mathrm{G})\end{array}$ & $\begin{array}{l}\text { The beginning } \\
\text { of fat, peach- } \\
\text { blossom-like }\end{array}$ & & $\begin{array}{l}\text { Live with quiet } \\
\text { surrounding }\end{array}$ & $\begin{array}{l}\text { Careful } \\
\text { care }\end{array}$ & $\begin{array}{l}\text { No acrid } \\
\text { foods }\end{array}$ & $\begin{array}{l}\text { Ai Ye Tang } \\
\text { (mugwort leaf } \\
\text { decoction) }\end{array}$ & $\begin{array}{c}\text { Foot } \\
\text { Shaoyang } \\
\text { gallbladder }\end{array}$ & Arthralgia \\
\hline Third & $\begin{array}{l}\text { Hand Shaoyin } \\
\text { heart }(\mathrm{H})\end{array}$ & $\begin{array}{l}\text { Non- } \\
\text { distinguished } \\
\text { sexes }\end{array}$ & $\begin{array}{l}\text { Formation of } \\
\text { blood and } \\
\text { vessels }\end{array}$ & $\begin{array}{l}\text { What the mother } \\
\text { see can affect the } \\
\text { development of } \\
\text { embryo }\end{array}$ & $\begin{array}{l}\text { Avoidance } \\
\text { of grief }\end{array}$ & & $\begin{array}{l}\text { Xiong Ji Tang } \\
\text { (cock decoction) }\end{array}$ & $\begin{array}{l}\text { Hand } \\
\text { Shaoyin } \\
\text { heart }\end{array}$ & $\begin{array}{c}\text { Loose } \\
\text { stool }\end{array}$ \\
\hline Fifth & $\begin{array}{l}\text { Foot } \\
\text { Taiyin } \\
\text { spleen }\end{array}$ & $\begin{array}{l}\text { Formation of } \\
\text { four } \\
\text { extremities }\end{array}$ & $\begin{array}{l}\text { Formation of } \\
\text { five Zhang } \\
\text { organs }\end{array}$ & $\begin{array}{l}\text { Avoidance of } \\
\text { cold wind }\end{array}$ & $\begin{array}{l}\text { Avoidance } \\
\text { of horror }\end{array}$ & $\begin{array}{l}\text { Lamb and } \\
\text { beaf }\end{array}$ & $\begin{array}{c}\text { E Jiao Tang } \\
\text { (donkey-hide } \\
\text { gelatin decoction) }\end{array}$ & $\begin{array}{c}\text { Foot } \\
\text { Taiyin } \\
\text { spleen }\end{array}$ & Vertigo \\
\hline Sixth & $\begin{array}{c}\text { Foot } \\
\text { Yangming } \\
\text { stomach (ST) }\end{array}$ & $\begin{array}{l}\text { Formation of } \\
\text { eyes and } \\
\text { mouth }\end{array}$ & $\begin{array}{l}\text { Functional } \\
\text { formation of six } \\
\text { Fu organs }\end{array}$ & Walk outside & $\begin{array}{l}\text { Avoidance } \\
\text { of terrify }\end{array}$ & $\begin{array}{l}\text { Sweet } \\
\text { foods }\end{array}$ & $\begin{array}{c}\text { Mai Men Dong Tang } \\
\text { (Ophiopogonis } \\
\text { Radix decoction) }\end{array}$ & $\begin{array}{l}\text { Foot } \\
\text { Yangming } \\
\text { stomach }\end{array}$ & $\begin{array}{c}\text { Abdominal } \\
\text { distension }\end{array}$ \\
\hline Seventh & $\begin{array}{l}\text { Hand } \\
\text { Taiyin } \\
\text { lung (L) }\end{array}$ & $\begin{array}{l}\text { Generation of } \\
\text { hair (on the } \\
\text { head and } \\
\text { body) }\end{array}$ & $\begin{array}{l}\text { Formation of } \\
\text { bone }\end{array}$ & $\begin{array}{l}\text { Gently physical } \\
\text { activities }\end{array}$ & $\begin{array}{c}\text { Avoidance } \\
\text { of panic }\end{array}$ & $\begin{array}{l}\text { No cold } \\
\text { foods }\end{array}$ & $\begin{array}{l}\text { Cong Bai Tang } \\
\text { (onion white } \\
\text { decoction) }\end{array}$ & $\begin{array}{c}\text { Hand } \\
\text { Yangming } \\
\text { large intestine }\end{array}$ & $\begin{array}{l}\text { Dysphoria } \\
\text { and fever }\end{array}$ \\
\hline Ninth & $\begin{array}{c}\text { Foot } \\
\text { Shaoyin } \\
\text { kidney }(\mathrm{K})\end{array}$ & $\begin{array}{l}\text { Ability of } \\
\text { physical to } \\
\text { turning } \\
\text { around }\end{array}$ & $\begin{array}{c}\text { Entry of Food } \\
\text { Qi into } \\
\text { stomach }\end{array}$ & Loose clothes & $\begin{array}{c}\text { Easily } \\
\text { contented }\end{array}$ & $\begin{array}{l}\text { Sweet wine } \\
\text { and foods }\end{array}$ & $\begin{array}{c}\text { Ban Xia Tang } \\
\text { (pinellia decoction) }\end{array}$ & $\begin{array}{l}\text { Foot } \\
\text { Shaoyin } \\
\text { kidney }\end{array}$ & $\begin{array}{l}\text { Rebellious } \\
\text { qi invading } \\
\text { upward to } \\
\text { heart }\end{array}$ \\
\hline Tenth & & $\begin{array}{l}\text { Formation of } \\
\text { five Zang } \\
\text { organs }\end{array}$ & $\begin{array}{l}\text { Fully formation } \\
\text { of body and } \\
\text { mind }\end{array}$ & & & & $\begin{array}{l}\text { Herbs promoting } \\
\text { delivery }\end{array}$ & & \\
\hline
\end{tabular}


meaning of fetus education basically refers to favorable psychological condition which affect embryo through an unknown communication pathway. In other words, what the mother thinks, sees, talks and does are prenatal parameters for postnatal development of fetus. Fetus education consists of harmonizing emotion, cultivation of knowledge, influence of environment, sexual abstinence, and good deeds.

\section{Discussion}

Inscriptions on oracle bones such as Nü (woman) and $M u$ (mother) 3200 years ago provide truthful evidence of ancient female behaviors like pregnancy, regeneration, and lactation. The inscriptions and literature of the names of gynecological disorders show the theoretical budding of female, gynecological, and obstetrical nursing. This is premature than other civilizations, medical systems, gynecology histories, and nursing histories [7]. As a branch of TCM, TCM gynecology and TCM gynecological nursing has developed precociously according to the record in The Yellow Emperor of Classics of Inner Medicine. Nowadays gynecology and gynecological nursing in TCM are still beneficial to woman [14-16].

The developing history of TCM is never interrupted by the turbulent Chinese history with dynastic change and regime separation. The six stages are continual developments and sustainable growth. Gynecology and gynecological nursing in TCM has been developing following the core principle of TCM or holism [17]. For thousands years, Chinese women have trusted traditional Chinese medicine to help them conceive. Gynecology and gynecological nursing originate from practices and are applicable in both TCM and western medicine. However, TCM nursing attaches importance to functional regulation, while western medicine nursing to anatomy and experiment [18]. Although TCM has rough perception of uterine, breast, virgin, and fetus, but TCM advocates to Zang Xiang (organs and their manifestations) rather than intensive anatomic study [19]. Table 2 shows metaphors if fetus of different months. Nevertheless the exact forms of fetus are not the emphases of TCM gynecology. TCM lays stress on the importance of functional regulation and adequate correct educational information for gravida [20]. All the ancient understanding about gynecological nursing approaches in TCM has been proven applicative, effective, simple, and feasible, which might be popularized.

Besides the conventional therapeutic and nursing strategies, TCM is performed in professional clinical practices and is showing a bright future in treating gynecology disorders, with its alternative approaches includeing acupuncture, moxibustion, herbal remedy, qigong, etc. [1]. There are plenty of reports on the beneficial outcomes of TCM gynecological practice and nursing on the various gynecological and obstetrical disorders, such as menopause [21], infertility [16], dysfunctional uterine bleeding (DUB) [22], labor pain [23], and breast cancer nursing [24].

\section{Conclusions}

TCM harbors a long history in regards to treating gynecological disorders and provides unique gynecological nursing. With therapeutic and nursing modalities, they are effective systems of understanding and managing woman health as proven by medical literatures, clinical benefits and basic research studies. TCM and conventional medicine share common goals in gynecology and nursing: benefit woman and guarantee human reproducetion.

\section{Acknowledgements}

This study was supported by National Science Funds of China under grant number, 81072719.

\section{Conflict of Interest Statement}

No conflict of interest declared.

\section{References}

[1] B. C. Maggie, "Traditional Chinese Medicine in the Treatment of Diabetes,” Diabetes Spectrum, Vol. 14, No. 3, 2001, pp. 154-159. doi:10.2337/diaspect.14.3.154

[2] J. P. Liu, M. Zhang, W. Y. Wang and S. Grimsgaard, "Chinese Herbal Medicines for Type 2 Diabetes Mellitus," The Cochrane Collaboration Cochrane Reviews, No. 3, CD003642.

[3] B. Zell, J. Hirata, A. Marcus, B. Ettinger, A. Pressman, K. Ettinger, et al., "Diagnosis of Symptomatic Postmenopausal Women by Traditional Chinese Medicine Practitioners,” Menopaus, Vol. 7, No. 2, 2007, pp. 129-134.

[4] G. Maciocia, "Obstetrics and Gynecology in Chinese Medicine,” Oxford, Churchill Livingstione, 1998, pp. 3-4.

[5] A. D. J. Lesley, "Hippocrates' Woman: Reading the Female Body in Ancient Greece (Review)," Bulletin of the History of Medicine, Vol. 74, No. 4, 2000, pp. 812-813. doi:10.1353/bhm.2000.0173

[6] M. Dumont, "Gynecology and Obstetrics in Ancient Rome," Revue Francaiçe de Gynécologie et d'Obstétrique, Vol. 87, No. 10, 1992, pp. 493-496, 499-505.

[7] R. Haimov-Kochman, Y. Sciaky-Tamir and A. Hurwitz, "Reproduction Concepts and Practices in Ancient Egypt Mirrored by Modern Medicine," European Journal of Obstetrics Gynecology and Reproductive Biology, Vol. 123, No. 1, 2005, pp. 3-8. 
[8] A. N. Jadhav and K. K. Bhutani, "Ayurveda and Gynecological Disorders,” Journal of Ethnopharmacology, Vol. 97, No. 1, 2005, pp. 151-159. doi:10.1016/j.jep.2004.10.020

[9] H. Zhang, C. E. Tan, H. Z. Wang, S. B. Xue and M. Q. Wang, "Study on the History of Traditional Chinese Medicine to Treat Diabetes," European Journal of Integrative Medicine, Vol. 2, No. 1, 2010, pp. 41-46.

[10] C. Smith, M. Coyle and R. J. Norman, "Influence of Acupuncture Stimulation on Pregnancy Rates for Women Undergoing Embryo Transfer," Fertility and Sterility, Vol. 85, No. 5, 2006, pp. 1352-1358. doi:10.1016/j.fertnstert.2005.12.015

[11] Y. Zhang, "Textual Research on Medicine in Oracle InScriptions of the Shang (Yin) Period (c 16th-11th Century B.C.),” Chinese Journal of Medical History, Vol. 16, No. 1, 1986, pp. 15-23.

[12] P. U. Unschuld, "Huang Di Nei Jing Su Wen: Nature, Knowledge, Imagery in an Ancient Chinese Medical Text," Journal of Alternative and Complementary Medicine, Vol. 10, No. 1, 2004, pp. 91-196.

[13] Z. H. Wang and J. Kang, "Treating Gynecological Disorders by the Treatment of Liver in Golden Chamber," Hebei Medicine, Vol. 3, No. 2, 1997, pp. 60-70.

[14] B. Q. Shen, Y. Situ, J. L. Huang, X. M. Su, W. T. He, M. W. Zhang, et al., "A Clinical Study on the Treatment of Chronic Pelvic Inflammation of Qi-Stagnation with Blood Stasis Syndrome by Penyanqing Capsule," Chinese Journal of Integrative Medicine, Vol. 11, No. 4, 2005, pp. 249-254. doi:10.1007/BF02835784

[15] X. Xu, H. Yin, D. Tang, L. Zhang and R. G. Gosden, "Application of Traditional Chinese Medicine in the Treatment of Infertility,” Human Fertility (Cambridge), Vol. 6, No. 4, 2003, pp. 161-168. doi:10.1080/1464770312331369433

[16] J. J. Zheng, P. Lu and Y. Zhao, "Research on Tuina
Treatment for Postpartum Hypolactation,” Chinese Acupuncture \& Moxibustion., Vol. 29, No. 6, 2009, pp. 501503.

[17] T. K. S. Wong and S. Pang, "Holism and Caring: Nursing in the Chinese Health Care Culture Holistic," Nursing Practice, Vol. 15, No. 1, 2000, pp. 12-21.

[18] H. M. Langevin and J. A. Yandow, "Relationship of Acupuncture Points and Meridians to Connective Tissue Planes,” The Anatomical Record, Vol. 269, No. 6, 2002, pp. 257-265.

[19] G. X. Chu and Q. Z. Li, “About 'Xiang' in Traditional Chinese Medicine,” Journal of Chinese Integrative Medicine, Vol. 6, No. 3, 2008, pp. 249-252.

[20] S. Andersson and T. Lundeberg, "Acupuncture-From Empiricism to Science: Functional Background to Acupuncture Effects in Pain and Disease Pain and Disease," Medical Hypotheses, Vol. 45, No. 3, 1995, pp. 271-281. doi:10.1016/0306-9877(95)90117-5

[21] L. Venzke, J. F. Calvert Jr. and B. Gilbertson, “A Randomized Trial of Acupuncture for Vasomotor Symptoms in Post-Menopausal Women," Complement Therapies in Medicine, Vol. 18, No. 2, 2010, pp. 59-66. doi:10.1016/j.ctim.2010.02.002

[22] N. N. Jin and K. Ma, "Study of Traditional Chinese Medicine Syndrome Factors of Dysfunctional Uterine Bleeding Based on Cluster Analysis and Factor Analysis," China Journal of Chinese Materia Medica, Vol. 33, No. 13, 2008, pp. 1622-1625.

[23] F. Qu and J. Zhou, "Electro-Acupuncture in Relieving Labor Pain,” Evidence-Based Complementary and Alternative Medicine, Vol. 4, No. 1, 2007, pp. 125-130.

[24] P. B. Simpson, "Family Beliefs about Diet and Traditional Chinese Medicine for Hong Kong Women with Breast Cancer," Oncology Nursing Forum, Vol. 30, No. 5, 2003, pp. 834-840. doi:10.1188/03.ONF.834-840 